\title{
Detection of Bhendi Yellow Vein Mosaic Virus (BYVMV) from the Different Parts of Bhendi [Abelmoschus esculentus (L.) Moench] Plant, Flower and Seed
}

\author{
Priyal Sisodia and Lalit Mahatma* \\ Department of Plant Pathology, N.M. College of Agriculture, Navsari Agricultural University, \\ Navsari 396450 Gujarat (India) \\ *Corresponding author
}

\section{A B S T R A C T}

\section{Keywords}

Begomovirus, BYVMV, Okra, Bhendi, Seed borne infection

\section{Article Info}

Accepted:

05 February 2020

Available Online:

10 March 2020
During the present investigation yellow vein mosaic disease in bhendi (Abelmoschus esculentus (L.) Moench) caused by a whitefly Bemisia tabaci (Gennadius) (Hemiptera: Aleyrodidae) transmitted Begomovirus particularly Bhendi yellow vein mosaic virus [INNVS-2018] or BYMV [IN-NVS-2018] or BYMV was characterized by symptoms of homogenous interwoven network of yellow veins enclosing islands of green tissues. In extreme cases, the infected leaf becomes totally light yellow or cream colored. The fruits of the infected plants exhibit pale yellow color, become deformed, small and tough in texture. Modification of the Doyle and Doyle (1987) method for the DNA extraction in which instead of $750 \mu 1$ each CTAB buffer and Chloroform: Isoamyl Alcohol (1:24), $1000 \mu 1$ each pre-heated CTAB extraction buffer Chloroform: Isoamyl Alcohol (1:24) was used for the proper precipitation of proteins and carbohydrates and yielded good quality of DNA. The presence of BYMV was detected from all the part tested viz., tip of the stem, tip of the root, flower bud, fruit, petel, sepal, ovary, pollen, seed coat, cotyledon and embryonic axis. Results indicated that the virus is present in all the parts of the plants including, vegetative and reproductive parts of the flowers as well as in seeds. However, in grow out test, none of the sample showed symptoms on the seedling. Therefore, it can be concluded that the virus is present in the seed, however, is not seed transmitted. From the best of our knowledge, this is the first report in the world which sowed the presence of BYVMV in bhindi seeds.

\section{Introduction}

Begomovirus, a genus of plant viruses belong to Geminiviridae family has emerged as one of the most destructive virus in the recent past. Different species of the genus named as per the template of "Host symptom virus" (e.g., Bean golden mosaic virus) causes diseases in many hosts and has been considered to be exclusively transmitted by its insect vector whitefly, Bemisia tabaci (Gennadius) (Hemiptera: Aleyrodidae). The concept that Begomovirus are not present in seed was challenged and rejected when presence of a Begomovirus, Mungbean yellow mosaic virus (MYMV) was reported from the 
different parts of the seed, viz., pod, seed coat, and cotyledon of mungbean (Vigna radiata L.) cv GM-4 from the Navsari (Gujarat) India (Pawar, 2010, Pawar and Mahatma, 2014, Pawar et al., 2015, Mahatma and Pawar, 2015, Mahatma et al., 2016). Subsequently presence of Sweet potato leaf curl virus (SPLCV) in sweet potato seed (Kim et al., 2015), Tomato yellow leaf curl virus (TYLCV) in tomato seed (Kil et al., 2015), Mungbean yellow mosaic virus (MYMV) in blackgram seed (Kothandaraman et al., 2016) have been reported.

This might have led, Begomovirus to emerge as one of the most diverse and destructive pathogen in the present scenario. However, we neglected the issue and considered the emergence and spread of the super vector $B$. tabaci as a sole reason for the emergence of plant virus disease outbreaks as well as multiple paradigm shifts (Gilbertson et al., 2015). This is very important as presently quarantine laws do not exist for the check of movement of any of the Begomovirus through seeds.

During the survey in 2015-2016 in south Gujarat (India), heavy incidence of a whitefly transmitted Begomovirus, Bhendi yellow vein mosaic virus (BYVMV) or Okra yellow vein mosaic virus (OYVMV) has been observed in bhendi (okra) crop. The symptoms were typically yellow vein mosaic type. The isolate was tentatively identified as Bhendi yellow vein mosaic virus [IN-NVS-2018] abbreviated as BYVMV [IN-NVS-2018] on the basis of partial sequencing of the DNA-A molecule of the virus (Ghevariya and Mahatma, 2017a, Ghevariya and Mahatma, 2017b). This is commonly referred as BYVMV. The pattern of outbreaks and spread of BYVMV revealed the chances of role of seed in the providing primary source of inoculum. Therefore, present investigation was carried out to detect the Begomovirus from the different parts of plant, flower and seed.

\section{Materials and Methods}

\section{Sources of samples}

Attempts were made to detect the presence of the virus from different parts of the plant flower and seed by PCR. For the study, graft transmission of previously characterized isolate BYVMV [IN-NVS-2018] was performed by approach and side veneer grafting method (Ghevaria and Mahatma, 2017a) in the greenhouse. A susceptible variety (Gujarat Okra-2,) was used for all the experiments. After graft transmission, bhendi plants showing clear and conspicuous symptoms of the BYVMV were tagged and floral buds/ flowers were collected in the early hours. Different parts of the flower (sepal, petal, androecium and gynoecium) were dissected under the stereoscopic microscope with the help of sterilized pointed forceps and kept separately. Utmost care was taken to avoid contamination. Seeds from the minimum 30 days old infected plants were collected separately and used after drying and storing them for one year. Different parts of the seed (seed coat, embryonic axis, and cotyledon) were separated after soaking the seeds in water for 6 hours. DNA from the different tissues was isolated and PCR was carried out to detect virus in the different tissues.

\section{Extraction of DNA from the bhendi plant parts}

Genomic DNA from the different parts of bhendi (infected as well as healthy) was isolated by the little modification of the method given by Doyle and Doyle (1987). Bhendi crop contain high level of mucilage and polyphenol; therefore, it was difficult to obtain the quality DNA. For obtaining quality DNA, tissue was macerated in liquid nitrogen. Instead of $750 \mu 1$ each CTAB buffer and Chloroform: Isoamyl Alcohol (1:24), 1000 $\mu 1$ 
each pre-heated CTAB extraction buffer and Chloroform: Isoamyl Alcohol (1:24) was used for the proper precipitation of proteins and carbohydrates. Polyvinyl pyrrolidone (PVP) was added in the CTAB buffer to remove phenolic compounds and 2-Mercaptoethanol was added as reducing agent which removes tannins and other polyphenols. Quality and quantity of DNA was checked by using NanoDrop ND-1000 spectrophotometer and on 0.8 per cent $(\mathrm{w} / \mathrm{v})$ agarose gel. A DNA sample was reported as high quality if it had a low amount of RNA.

PCR for the detection of BYVMV in different parts

PCR was performed using degenerate primers (LVF=TCTCAACTTCGACAGCCCATC $+\mathrm{L}$ $\mathrm{VR}=$ ATAGGTCCAGTGGCGTTTGA) for the Begomovirus which amplifies approx. 700 bp sequence of DNA-A molecule particularly the AV-1 gene synthesizing coat protein (Kalaria et al., 2013). For a $25 \mu 1$ reaction, 10x Taq buffer $(2.5 \mu \mathrm{l}), \quad 3 \mathrm{U} / \mu \mathrm{l}$ TaqDNA polymerase $(0.6 \mu \mathrm{l})$, dNTPs $(0.6 \mu \mathrm{l}), \mathrm{MgCl}_{2}$ $(2.0 \mu 1)$, DNA template $(2.0 \mu 1)$, forward and reverse primer $2.0 \mu 1$ of 10 pmolesml $^{-1}$ each and $13.3 \mu \mathrm{l}$ sterilized Millipore water were used. The cycling programme including a first cycle of $5 \mathrm{~min}$ at $94^{\circ} \mathrm{C}$, followed by 35 cycles of $45 \mathrm{~s}$ at $94^{\circ} \mathrm{C}, 45 \mathrm{~s}$ at the annealing temperature, followed by $1 \mathrm{~min}$ at $72^{\circ} \mathrm{C}$, and a final extension of $10 \mathrm{~min}$ at $72^{\circ} \mathrm{C}$ was set in thermal cycler for the PCR reaction. PCR products were electrophoresed on 1.2 per cent (w/v) agarose gels, in $0.5 \mathrm{X}$ TBE buffer at $80 \mathrm{~V}$ for 1 hour, stained with ethidium bromide $\left(0.5 \mu \mathrm{g} \mathrm{ml}^{-1}\right)$ and documented under UV light using Syngene Bio imaging system (UK).

\section{Grow out test}

Four hundred seeds each from graft transmitted symptomatic and disease free control plants were collected, dried, potted separately and maintained in insect proof cages in an insect-free greenhouse. Plants were observed periodically for symptom appearance.

PCR amplifications were performed with second leaves of forty randomly selected seedlings kept for grow out test.

\section{Results and Discussion}

\section{Appearance of disease (Sources of samples)}

Disease symptoms appeared with the appearance of true leaves and were seen at all the stages of the growth. The YVMD is characterized by symptoms of homogenous interwoven network of yellow veins enclosing islands of green tissues. Initially infected leaves exhibited only yellowing of the veins and veinlets but in the later stages, the entire leaf turned completely yellow.

In extreme cases, the infected leaf becomes totally light yellow or cream colored. Plants infected at the early stages remain stunted. The fruits of the infected plants exhibit pale yellow color, become deformed, small and tough in texture. The results were in accordance with the Kulkarni (1924) and Ghevaria and Mahatma (2017a).

\section{Extraction of DNA from the bhendi plant parts}

DNA/RNA ratio obtained in different isolated DNA ranged 1.80 to 1.88 in different samples. Result showed that the DNA was pure and free from proteins and RNA. Similarly, the DNA was also tested by running it on 0.8 percent (w/v) agarose gel. On agarose gel, DNA was having a very thick band from all the samples indicating good quality DNA from the different samples. 
PCR for the detection of BYVMV in different parts

Study indicated that the degenerate primers used in the present investigation amplified approx. $700 \mathrm{bp}$ amplicon of virus from the DNA-A molecule. The per cent detection of virus from the leaf, tip of the stem and root tip was 100 per cent in which all the ten samples tested showed presence of virus. However, only 8 ( 80.0 per cent) out of the 10 samples tested showed positive results in the infected flower bud and fruit. Also, the DNA was extracted from the infected petal, sepal, ovary, pollen and from seed coat, cotyledon and embryonic axis. The per cent detection of virus from petal and sepal was 60.0 per cent where out of the 10 samples, only 6 samples showed positive reaction with the primers used. In ovary and pollen, 50.0 per cent sample showed presence of virus (five samples out of ten samples) when tested by the PCR (Table-1, Fig-1\&2).
The virus detection per cent in embryonic axis was 50.0 per cent, seed coat was 60 per cent and cotyledon was 80.0 per cent where 5,6 and 8 samples respectively out of 10 samples tested showed amplification of the specific band of approx. 700bp (Table-1, Fig-3). Pawar (2010), Pawar and Mahatma (2014) and Mahatma and Pawar (2015) also detected the presence of virus from the different parts of flower (sepal, petal, and androecium) and seed (seed coat and cotyledon). However, they did not observed virus from the gynoecium of the flower and embryonic axis of the seed. Kothandarman et al., (2016) observed MYMV from the blackgram embryonic axis too. Other have not attempted to detect the virus from the individual seed part might be because of the small size of the seed. However, presence of Sweet potato leaf curl virus (SPLCV) in whole sweet potato seed (Kim et al., 2015), Tomato yellow leaf curl virus (TYLCV) in whole tomato seed (Kil et al., 2015) have been reported in whole seed.

Table.1 Detection of BYVMV by PCR in different parts of bhendi

\begin{tabular}{|r|l|c|c|c|}
\hline $\begin{array}{r}\text { Sr. } \\
\text { No. }\end{array}$ & \multicolumn{1}{|c|}{ Plant part } & No. of sets & $\begin{array}{c}\text { No. of PCR positive sets/ } \\
\text { No. of sets tested }\end{array}$ & $\begin{array}{c}\text { Per cent } \\
\text { Infection }\end{array}$ \\
\hline $\mathbf{1 .}$ & Infected leaf & 10 & $10 / 10$ & 100.0 \\
\hline $\mathbf{2 .}$ & Tip of stem & 10 & $10 / 10$ & 100.0 \\
\hline $\mathbf{3 .}$ & Root tip & 10 & $10 / 10$ & 100.0 \\
\hline $\mathbf{4 .}$ & Flower bud & 10 & $8 / 10$ & 80.0 \\
\hline $\mathbf{5 .}$ & Fruit & 10 & $8 / 10$ & 80.0 \\
\hline $\mathbf{6 .}$ & Petal & 10 & $6 / 10$ & 60.0 \\
\hline $\mathbf{7 .}$ & Sepal & 10 & $6 / 10$ & 60.0 \\
\hline $\mathbf{8 .}$ & Ovary & 10 & $5 / 10$ & 50.0 \\
\hline $\mathbf{9 .}$ & Pollen & 10 & $5 / 10$ & 50.0 \\
\hline $\mathbf{1 0 .}$ & Seed coat & 10 & $6 / 10$ & 60.0 \\
\hline $\mathbf{1 1}$. & Cotyledon & 10 & $8 / 10$ & 50.0 \\
\hline $\mathbf{1 2}$. & Embryonic axis & 10 & $5 / 10$ & 50.0 \\
\hline
\end{tabular}



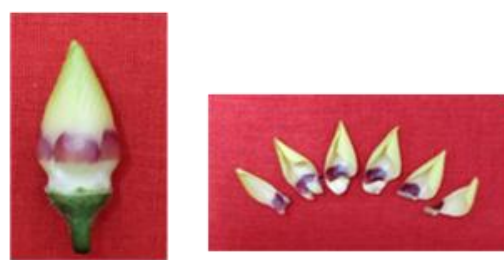

(a) Flow er bud (Healthy)

(b) Petals (Infected)

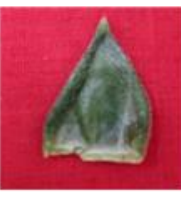

(c) Sepals (Infected)

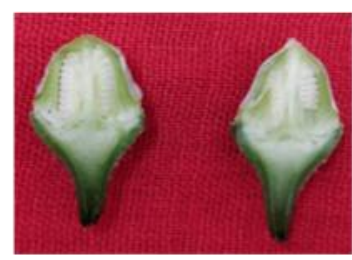

(d) Ovary (Infected)

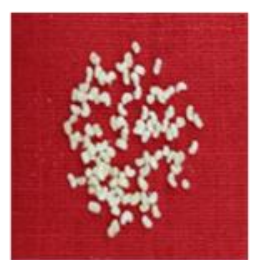

Pollens (Infected)

Fig 1. Different parts of the okra flower tested for the presence of Begomovirus (a) healthy flower bud, (b) infected petals, (c) sepals (d) ovary and (e) pollens

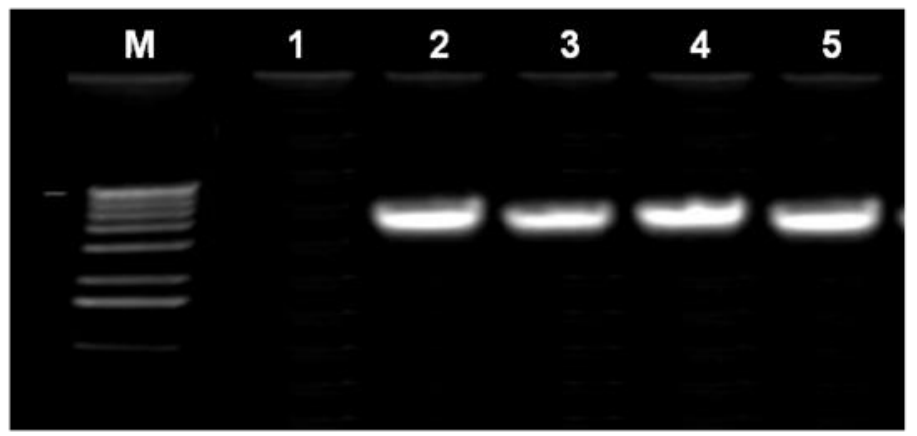

Fig 2. PCR analysis of different parts of flower lane M: $100 \mathrm{bp}$ marker, lane 1: healthy flower bud, lane 2: infected petals, lane 3: infected sepals, lane 4: infected ovary and lane 5: infected pollens
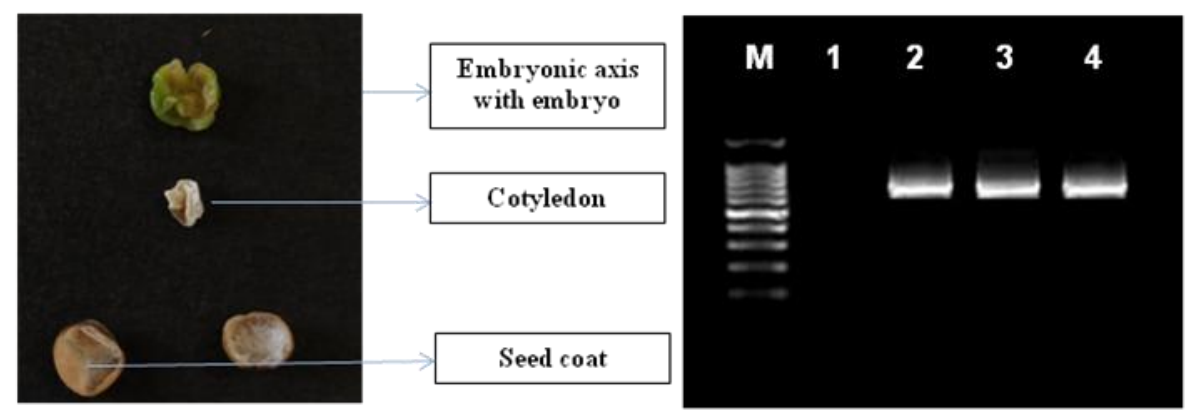

M: 100 bp DNA ladder

1: Healthy control

2:Seed coat (Infected)

3: Cotyledon (Infected)

4: Embry onic axis (Infected)

Fig 3. Different parts of the okra seeds tested for the presence of Begomovirus and PCR analysis of different parts of seeds lane M: 100 bp marker, lane 1: healthy control, Iane 2: infected seed coat, Iane 3: infected cotyledon, lane 4: infected embryonic axis

\section{Grow out test}

More than 95 per cent germination was observed in both infected and healthy seeds. None of the plant germinated out of the 400 hundred seeds of each category tested showed any type of symptoms. Further, none of the plant out of the forty plants tested showed presence of positive reaction in the PCR
In conclusion, disease symptoms appeared with the appearance of true leaves and were seen at all the stages of the growth. The YVMD was characterized by symptoms of homogenous interwoven network of yellow veins enclosing islands of green tissues. Initially infected leaves exhibited only yellowing of the veins and veinlets but in the later stages, the entire leaf turned completely 
yellow. In extreme cases, the infected leaf becomes totally light yellow or cream colored. Plants infected at the early stages remain stunted. The fruits of the infected plants exhibit pale yellow color, become deformed, small and tough in texture. Bhendi crop contain high level of mucilage and polyphenol; therefore, it was difficult to obtain the quality DNA. Modification of the Doyle and Doyle (1987) method for the DNA extraction in which instead of $750 \mu$ each CTAB buffer and Chloroform: Isoamyl Alcohol (1:24), 1000 $\mu 1$ each pre-heated CTAB extraction buffer Chloroform: Isoamyl Alcohol (1:24) was used for the proper precipitation of proteins and carbohydrates and yielded good quality of DNA. Polyvinyl pyrrolidone (PVP) was added in the CTAB buffer to remove phenolic compounds and 2Mercaptoethanol was added as reducing agent which removes tannins and other polyphenols. The protocol was found better for the extraction of DNA from the different samples. Study indicated that the degenerate primers used in the present investigation amplified approx. 700 bp amplicon of virus from the DNA-A molecule.

The presence of Begomovirus, particularly Bhendi yellow vein mosaic virus [IN-NVS2018] or BYMV [IN-NVS-2018] or BYMV was detected from all the part tested viz., tip of the stem, tip of the root, flower bud, fruit, petel, sepal, ovary, pollen, seed coat, cotyledon and embryonic axis. Results indicated that the virus is present in all the parts of the plants including, vegetative and reproductive parts of the flowers as well as in seeds. However, in grow out test, none of the sample showed symptoms on the seedling. Therefore, it can be concluded that the virus is present in the seed. From the best of our knowledge, this is the first report in the world which sowed the presence of BYVMV in bhindi seeds.
A thin difference is there in the virus present in the seed and seed transmitted viruses. Only those viruses, which are transmitted from seed to seedling, are considered as seed transmitted viruses. Grow out test suggest that the virus, particularly, BYVMV in bhendi is not seed transmitted virus. Our results are contradicting the results of (direct) seed transmission of Begomovirus reported by Kim et al., (2015) (Sweet potato leaf curl virus through sweet potato seed), Kil et al., (2015) (Tomato yellow leaf curl virus through tomato seed), Kothandaraman et al., (2016) (Mungbean yellow mosaic virus through blackgram seed) and Kil et al., (2016) (Tomato yellow leaf curl virus through white soybean seed).

Here we experimentally conclude that BYVMV in bhendi is a typical example of the virus present in the seeds. Mahatma and Pawar (2015) proposed indirect path of seed to seedling transmission of Begomovirus in which insect vector whitefly play very important role. There might be chances that the BYMV in okra can also be indirectly seed transmitted. We need to experimentally prove to draw any conclusion. In spite of excellence in science, it took long time to find out that Begomovirus are present in the seeds. This might be because, indirect route is followed by the virus. In either case we need to reconceptualize the concept of seed borne and seed transmitted viruses.

\section{References}

Doyle, J. J. and Doyle, J. L. (1987). A rapid DNA isolation procedure for small quantities of fresh leaf tissue. Phytochemical Bulletin, 19:1115.

Ghevariya, T. V. and Mahatma, L. (2017a). Biological characterization of Okra yellow vein mosaic virus (OYVMV) infecting okra in South Gujarat, India. 
International Journal of Current Microbiology and Applied Sciences, 6(7): 2017-2024.

Ghevariya, T. V. and Mahatma, L. (2017b). Molecular characterization of Okra yellow vein mosaic virus infecting okra in south Gujarat Pl. Dis. Res. 32 (2)206210

Gilbertson, R.L., Batuman, O, Webster, C.G. and Adkins, S. (2015). Role of the Insect Supervectors Bemisia tabaci and Frankliniella occidentalis in the Emergence and Global Spread of Plant Viruses. Аnnu Rev Virol. 2(1):67-93. doi: 10.1146/annurev-virology-031413085410

Kalaria, R., Mahatma, M. K. and Mahtma, L. (2013). Molecular characterization of Begomovirus infecting Abutilon glaucum in South Gujarat region. The Bioscan, 8(1): 105-107.

Kil, E. J., Kim, S., Lee, Y. J., Byun, H. S., Park, J., Seo, H., Kim, C. S., Shim, J. K., Lee, J. H., Kim, J. K., Lee, K. Y., Choi, H. S. and Lee, S. (2016). Tomato yellow leaf curl virus (TYLCV-IL): a seed transmissible Geminivirus in tomatoes. Scientific reports, 6:19013.

Kim, J., Kil, E. J., Kim, S., Seo, H., Byun, H. S., Parka, J., Chung, M. N., Kwak, H. R., Kim, M. K., Kim, C. S., Yang, J. W, Lee, K.Y., Choi, H. S. and Lee, S. (2015). Seed transmission of Sweet potato leaf curl virus in sweet potato (Ipomoea batatas). Plant Pathology, 64: 1284-1291.

Kothandaraman, S. V., Devadason, A. and Ganesan, M. V. (2016). Seed-borne nature of a Begomovirus, Mungbean yellow mosaic virus in black gram. Applied Microbial and Cell Physiology, 100:1925-1933.

Kulakarni, G. S. (1924). Mosaic and other related diseases of crops in the Bombay presidency. Poona Agric. College Magazine, 16:6-12.

Mahatma, L. and Pawar, D. M. (2015). Role of seed in the epidemiology of yellow mosaic virus disease in mungbean (Vigna radiata L.). Journal of Mycology and Plant Pathology, 45(4): 324-329.

Mahatma, L., Mahatma, M. K., Pandya, J. R., Solanki, R. K. and Solanki, V. A. (2016). Epidemiology of Begomoviruses: a global perspective. Plant Viruses: Evolution and Management. Springer, Singapore. pp171-188.

Pawar, D. and Mahatma, L. (2014). Investigation of Mungbean yellow mosaic virus on mungbean. LAP LAMBERT Academic Publishing (2014-04-29) ISBN-10 No 3659136166 pp72.

Pawar, D. M. (2010). Investigations on Mungbean yellow mosaic virus (MYMV) of mungbean (Vigna radiata (L.) Wilczek). M.Sc. Thesis submitted to NAU, Navsari.

Pawar, D. M., Patel, V. D., Patel, H. P., Chaujan, D. A., Mahatma, M. K., Mishra, A. and Mahatma, L. (2015). Role of seed in the Epidemiology of Mungbean yellow mosaic virus disease in Mungbean. Journal of Mycology and Plant Pathology, 45(2).

\section{How to cite this article:}

Priyal Sisodia and Lalit Mahatma. 2020. Detection of Bhendi Yellow Vein Mosaic Virus (BYVMV) from the Different Parts of Bhendi (Abelmoschus esculentus (L.) Moench) Plant, Flower and Seed. Int.J.Curr.Microbiol.App.Sci. 9(03): 389-395. doi: https://doi.org/10.20546/ijcmas.2020.903.046 